\title{
THE ADEQUACY OF REMEDIES AGAINST MONOPOLY UNDER STATE LAW
}

It is well known that the enactment of the Federal Anti-Trust Act of 1890 was largely induced by a prevalent belief that the remedies obtainable under State law against what are commonly known as "monopolies" or "trusts," were inadequate.

At about the same time, that is in 1889 , commenced the era of State anti-trust legislation, in force in so many of the States. It may be conceded that as matters now are, such legislation is, generally speaking, without application to what is strictly commerce or transportation within the scope of the commerce clause, conferring upon Congress what is (though not in terms) the exclusive power "to regulate commerce with foreign nations and among the several States." 1 But this can doubtless be explained as merely an application of the general rule that the exercise of the power of Congress under such provision as here, by the Act of 1890 , excludes the exercise of any conflicting power under authority of a State. Other illustrations are legislation by way of regulation of immigration, ${ }^{2}$ and the Interstate Commerce Act. $^{3}$

But it does not follow that State anti-trust legislation would be equally ineffective in the absence of such legislation by Congress, and it should be borne in mind that for nearly twenty years there has been little or no opportınity to test the adequacy of such legislation, with reference to the application of the commerce clause.

Now, it is true that the power of Congress under such provision is, even in the absence of exercise thereof, exclusive of any exercise of power of a State to legislate by way of direct regulation of commerce within the scope thereof, ${ }^{4}$ at any rate

1 See for instance: Hadley Dean Plate Glass Co. v. Highland Glass Co., 143 Fed., 242 (C. C. A. 8th C. 1906); Statc v. Virginia Carolina Chemical Co., 71 S. C., 544, 559 (1905); Mooney Hardware Co. v. Goodzuin Pottery Co., rzo S. W., ro88 (Tex. Civ. App. I909).

${ }^{2}$ See People v. Compagnie Générale Transatlantique, 107 U. S., 59, 63 ( $\left.188_{3}\right)$.

${ }^{3}$ See Gulf, Colorado \& Santa Fe Ry. Co. v. Hefiey, 158 U. S., 98 (I895); Interstate Commerce Commission v. Detroit, Grand Haven, etc., Ry. Co., 167 U. S., 633, 642 (1897).

4 See, for instance, Asbell v. Kansas, 209 U. S., 25 I (Ig08). 
so far as concerns what have been called "matters national" as distinguished from "matters of local interest." " But it is equally true that the powers reserved to the States may be extensively and validly exercised, though such commerce is thereby affected. Thus it has been said: "The legislation of a State, not directed against commerce or any of its regulations, but relating to the rights, duties, and liabilities of citizens, and only indirectly and remotely affecting the operations of commerce, is of obligatory force upon citizens within its territorial jurisdiction, whether on land or water, or engaged in commerce, foreign or interstate, or in any other pursuit." ${ }^{\circ}$

Now it is beyond dispute that the powers reserved to the States include the power to enact anti-trust laws. ${ }^{7}$ That is to say, the States may prohibit the manufacture, sale, or transportation wholly within their limits of any article, if involving such a restriction upon competition as to amount to a "monopoly" or "trust." Under these conditions, is it likewise within the power of a State to prohibit or otherwise regulate the transportation of such article into the State, assuming the non-existence of the Federal Anti-Trust Act or other anti-trust legislation by Congress?

It also seems beyond dispute that, at least under certain conditions, the power of a State to prohibit or otherwise regulate the manufacture, sale, or transportation of an article, includes the power to prohibit or otherwise regulate the transportation thereof into the State. Thus, a State cannot, generally speaking, prohibit the transportation of cattle into the State. ${ }^{8}$ But it may prohibit such transportation of diseased cattle. ${ }^{9}$ So as to quarantine

SSee, for instance, Lcisy v. Hardin, 135 U. S., 100, 109 (1890).

B Sherlock $v$. Alling, 93 U. S., 99, ro4 (Oct., 1876). The court has repeatedly quoted this language with approval. See Plumley $v$. Massachusetts, I55 U. S., 46I, 473 (1894); Pittsburg \& Southern Coal Co. v. Louisana, "I56 U. S., 590; Louisville \& Nashville R. R. Co. v. Kentucky, 161 U. S., 677, 701 (1896); Lilz v. Hesterberg, 21I U. S., 31, 42 (1908).

'Such legislation was sustained in Smiley v. Kansas, I96 U. S., 447 (1905); National Cotton Oil Co. v. State, 197 U. S., I15 (1905); Carroll v. Grecuarich Ins. Co., 199 U. S., 401 (1905); Waters-Pierce Oil Co. v. Texas, 212 U. S., 86 (1909).

${ }^{8}$ Railroad Co. v. Husen, 95 U. S., 465 (Oct., 1877).

- Reid v. Colorado, 187 U. S., I37 (1902) ; Rasmussen v. Idaho, 181 U. S., Ig8 (Igor) ; Smith v. St. Louis \& Southwestern Ry. Co., I8I U. S., 248 (IgOI) ; Asbell v. Kansas, 209 U. S., 25I (Ig08). 
regulations preventing the transportation of persons. ${ }^{10}$ To the same principle seems referable the imposition of restrictions upon transportation into the State for the purpose of preventing fraud or deception in sales, thus, of oleomargarine.11 So as to the transportation of game for the purpose of exercising the "power to preserve a food supply" which belongs in common to all the people of the State. ${ }^{12}$

Considered by themselves, these decisions seem to have been rendered in analogous cases, and to furnish strong support for the view that the power of a State to enact anti-trust laws includes the power to prohibit or otherwise regulate the transportation of a monopolized article into the State. But it will be objected that this view is contradicted by the well-known decisions with reference to intoxicating liquors and oleomargarine.

Thus in Bowman v. Chicago, etc. Ry. Co., ${ }^{13}$ Leisy v. Hardin. ${ }^{14}$ was denied the power to prohibit the transportation of intoxicating liquors into the State. Undoubtedly some of the language of the opinions therein is not to be harmonized with the view I am here advocating. But my point is that on the facts they are in entire harmony with such view, being sustainable on the ground that as said in Leisy v. Hardin, ${ }^{15}$ the State cannot prohibit such transportation of "any articles which Congress recognizes as subjects of interstate commerce," it being denied that "whatever are thus recognized can be controlled by State laws amounting to regulations, while they retain that character." The same may be said of Schollenberger v. Pennsylvania, ${ }^{16}$ where in holding invalid restrictions upon the transportation of oleomargarine, it was said: "We think that what Congress thus taxes and recognizes as a proper subject of commerce cannot be wholly excluded from any particular State." In this view there is no necessary objection to the application of State anti-trust laws by way of prohibiting or otherwise regulating transportation into

\footnotetext{
${ }^{10}$ Compagnie Francaise de Navigation v. Louisiana State Board of Health, I86 U. S., 380, 387 (1902).

11 Plumley v. Massachusetts, I55 U. S., 46r (I894).

12 Lilz v. Hesterberg, 2II U. S., 3I (I908).

13 I25 U. S., 465 (I888).

${ }^{4}$ I 35 U. S., I00 (I890).

${ }^{15}$ p. I25. Compare as to tobacco, Austin v. Tennessee, I79 U. S., 343, 345 (1900).

${ }^{16}$ I7I U. S., I, I9 (I898).
} 
the State of an article not recognized by Congress as a proper subject of commerce.

Perhaps by the same rule it is within the power of a State to prohibit monopoly in the business of transportation into the State, as incident to its power to prohibit such monopoly of transportation within the State. This view may find support in Louisville \& Nashville R. R. Co. v. Kentucky, ${ }^{17}$ where was sustained, as applicable to a corporation engaged in interstate transportation, a prohibition against the consolidation of parallel or competing lines.

But if otherwise the power of a State to enact anti-trust laws does not include the power to prohibit transportation into the State, may not the obstacle be removed by Congressional legislation analogous to the Wilson Act of I890, giving effect to State legislation as to intoxicating liquors "upon arrival in such State?" This language has, indeed, been narrowed by judicial construction to arrival at the destination within the State, coupled with delivery to the consignee. ${ }^{18}$ But it may be that the provision would be equally applicable if including arrival at the boundary of the State. In this view, State anti-trust legislation would seem to have reasonably ample scope.

But even if the view just advocated be untenable, and State anti-trust statutes inapplicable to transportation into the State, there yet remains in the States a vast source of power derived from the principle established in Western Union Tel. Co. v. Call Publishing Co.," that "the principles of the common law are operative upon all interstate commercial transactions except in so far as thcy are modified by Congressional enactments." Here relief was held properly allowed in a State court against illegal discrimination even in transportation within the scope of the commerce clause. There seems no reason to doubt that the principle is equally applicable to relief against monopoly, so that the commerce clause of itself, in the absence of Congressional legislation thereunder furnishes no objection to the allowance in a State court of relief on common law grounds against transportation into the State under conditions of monopoly.

Whether criminal liability could be enforced by virtue of this principle may not be entirely clear, though the opinion has been

17 16I U. S., 677, 70I (1896).

${ }^{18}$ See Heyman v. Southern Ry. Co., 203 U. S., 270 (Ig06).

${ }^{19}$ T8I U. S., 92 (I9OI). 
frequently expressed that there exists on common law grounds, liability for acts producing or tending to produce restrictions upon competition. ${ }^{20}$

But, however this may be, it seems reasonably clear that there is available a remedy by way of injunction, on the application of the attorney-general. Thus, in Stockton v. Central $R$. $R$. of $N$. $J .{ }^{21}$ relief was so granted against action tending to create a monopoly in the business of transportation by railroad. Recently the principle involved was carried even further in $M c$ Carter v. Firemen's Ins. Co., ${ }^{22}$ where relief was so granted against action by corporations engaged in the business of fire insurance under an agreement to fix rates, it being said that if such agreement was "one that fixes rates and stifles competition, and is detrimental to the public, and if injury has thereby resulted to the public, the duty of a court of equity to enjoin the defendants from continuing to act $* * *$ is clear." Bearing in mind what we have just seen to be established, that the principles of the common lave are operative upon all interstate commercial transactions, it seems to inevitably follow that like relief would be allowable by way of injunction in a State court against transportation into the State under conditions of monopoly. And it will be observed that unlike the case of relief allowable under a State statute, the relief now under consideration would doubtless be allowable without reference to the existence of a monopoly in sale, manufacture or transportation wholly zeithin the State.

By way of summary, then it may be stated that in the view herein taken, assuming the non-existence of conflicting Congressional legislation, the pozver of a State to enact anti-trust laws includes the pozver to prohibit or otherwise regulate transportation into the State under conditions of monopoly; that even if this be not so, by virtue of application of "the principles of the common law operative upon all interstate commercial transactions" relief may be obtained against such transportation in the courts of the State. ${ }^{23}$

Ncw York City.

Frederick H. Cooke.

${ }^{20}$ Cooke on Combinations, Monopolics and Labor Unions, Sect. I63.

${ }^{21} 50$ N. J. Eq., 52. ( 1892 ).

${ }^{22} 73$ Atl., 80 (N. J. Ct. of Err. \& App., I909).

23 It will be recalled that this seems substantially the view advocated by Judge Parker in the presidential campaign of 1904 . 